\title{
Socio-Economic Impact of Flooding on Edo State: Case Study of Anegbette, Osomegbe, Udaba Communities and Environs
}

\author{
Isere Victoria Oshuare Imonikhe Justina Selimetu \\ Department of Humanities And Social Sciences, Auchi Polytechnic, Auchi
}

\begin{abstract}
Flooding is a growing menace all over the world. The people of Udaba, Anegbette, Osomegbe and AgbabuEkperi of Edo North, Nigeria have had some share of the flooding experience having had two bouts -2012 and 2018 as at the time of this research; causing severe loss of crops and source of income. This study was done to reveal the socio-economic impact of flooding on these people. A sample size of 1000 respondents was randomly selected among the residents of these communities. The data so gathered was analysed using SPSS. The findings revealed that flooding of these communities was caused by the heavy rains and the overflowing of the river Niger; the help rendered by the government was inadequate; the impact of the flood was much because of lack of information concerning the movement of the flood and that there is a significant difference between the economic life of the people before and after the flood. This paper recommends among others that there be adequate and timely information sent to these communities and that government intensify interventions to permanently better the life of these people.
\end{abstract}

Keywords: flooding, Udaba, Anegbette, Osomegbe, Agbabu-Ekperi, government intervention

DOI: $10.7176 / \mathrm{JESD} / 11-22-03$

Publication date: November $30^{\text {th }} 2020$

\section{Introduction}

The coming of the rains in African communities is greeted with much jubilation and ecstatic celebrations especially in rural areas. It is a welcome natural phenomenon that everybody looks forward to. The peasant farmers who have tilled the soil rejoice as they get approval from mother nature to go-ahead to plant their seeds. With the rains, comes a busy season for them as they rush to gladly plant their seeds. However, as the rains continue if drainage is compromised, floods can result in overtime. Flooding results mainly from prolonged and aggressive rainfall swelling water bodies beyond their natural and man-made limits. Flood is one of the most devastating natural disasters in the world; claiming human and animal lives as well as damaging properties and natural habitats. (Agbonkhese, Agbonhkese, Aka, Joe_Abay, Ocholi \& Adekunle, 2014; Etuonovbe, 2011 and Hewitt \& Sheehan, 1969).

Wikipedia (2018) defines a flood as an overflow of water that submerges usually dry land. It is also seen to occur when a body of water moves over an area of land which is usually unsubmerged. It is the inundation of an area through a temporary rise in the level of stream, river, lake or sea (Agbonkhese et al, 2014), while Elenwo (2015) defined flood as a body of water which rises to overflow land while Nkwunonwo (2016) said conceptually, flooding is water overtopping its natural and manmade defences and overflowing places not typically submerged. All over the world, flooding is a frightening growing menace. This is so because flooding is worsened by rapid urbanization; resulting in urban flooding; poor urban planning and climate change (Elenwo, 2015 \& Nkwunonwo, 2016). Flooding can also be caused by building across flood plains, indiscriminate dumping of refuse on flood plains and drainages.

Emeribeole (2015) also opined that increased road construction along rivers and concentration of population around submerged areas can induce flooding with increasing damage. Flooding resulting from urbanization comes from building across the natural watercourse. This can be heard across nations during the rainy seasons when rivers swell and overflow their banks. The most common cause of the flooding is river flooding which is often caused by excessive rainfall and climate change. These excess rainfall cause water bodies to rise and overtime it overflows into surrounding lands which can be residential or farmlands. This does a lot of damage to both human, livestock as well as other properties.

Flooding affects people negatively everywhere in the world; from America to Europe, from Pakistan and India to China and even Nigeria. The deadliest flood in recent history was caused by the hurricane Harvel which drenched Houston/Texas in the United States in 2017. Another deadly flooding in the US was brought by hurricane Katrina in 2005. (Grant, 2017). In France, it was reported that flood killed 12 persons when rainfall turned rivers into raging torrents in southwest France in October 2018 (Punchng.com, 2018). Wikipedia (2018) reports of the excessive heavy downpour in Japan in June/July 2018 which resulted in devastating floods and mudflows leaving a death toll of over 225 people. It was recorded as the deadliest freshwater flood-related disaster in Japan. When floods hit Chennai in 2015, Indian small businesses were adversely affected. Elrha.org (undated) reported the seven Taluks in the Cuddalore District were underwater. Approximately $450 \mathrm{~km}$ of village roads were damaged and the death toll reached 94 . 
Nigeria suffers from floods both in urban and rural centres. Flood menace has been a recurring decimal in urban areas like Port Harcourt, Kaduna, Lagos, Owerri and other cities with large rivers. (Aliyu \& Suleiman, 2016; Elenwo, 2015; Ijigah \& Akinyemi, 2015; Emeribeole, 2015). The losses incurred are usually large and varied. The rural areas are not spared even though much of their sufferings seem to go unreported. Emeribeole (2015) reported that $20 \%$ of the population in Nigeria is at risk of one form of flooding or the other. He reported that between July and October 2012, flooding in Nigeria submerged hundreds of thousands of acres of farmland and forced 1.3million people from their homes while over 430 lives were lost. Flooding submerges acres of farmlands and several other losses and lives. The teething problems and effects on peasant farmers and communities and possible government intervention have not been looked into by the government in Nigeria. It is against this background that the researchers seek to investigate the socio-economic impact of flooding in Anegbette, Osomegbe, Agbabu-Ekperi and Udaba communities of Edo state.

\section{Causes of Flooding}

A fundamental question is what causes flooding? An array of causes exist depending on the type of flood. Efobi and Anierobi (2013) opined that flooding is influenced by natural factors such as intensity and duration of rainfall; topography and geology of stream basins and other hydrological conditions. However, land use and other human activities are a major causative agent of flooding, especially on urban centres. B-Air (20180 gave eight common causes of flood. It categorized these eight as human causes and natural causes. The eight causes of flooding include:
a Heavy rains
b. Overflowing rivers
c. broken dams
d. $\quad$ storm surges, hurricanes and tsunamis
e. $\quad$ channel with steep sides
f. A lack of vegetation
g. melting snow and ice
h. Urban drainage basins

Almost everywhere flooding has been reported, it is observable that it is caused by heavy and prolonged rainfalls which cause rivers to overflow and spill into farmlands and residential areas causing severe damage to humans, livestock as well as infrastructure.

According to Nwigwe and Emberga (2014), there are three schools of thought about the prevalence of floods, especially in the tropics. The first is that global warming and climate change is leading to a gradual increase in the number of rains and melting ice thereby increasing volume and speed of run-off water. The second posit that there has been a lot of abuse of the physical environment by man (through indiscriminate dumping of refuse, building across the natural course of water, overfishing and the use of chemicals that loosen the soil making it susceptible to erosion); while the third school of thought combines the submission of the two earlier schools and posit that flooding is as a result of climate change and abuse of the physical environment. More research on these schools of thought is yet to be done.

Urban centres contain drainage systems that are built to help channel rainwater especially away from roads. These drains are desilted annually and sometimes the running water is rechanneled. This only transfers the water to another area which sooner than later becomes waterlogged and results in flooding. The urban flood can be reduced by designing efficient Storm Water Management (SWM) systems which are the best practices for stormwater management in the urban scenario.

Rural communities experience flooding, especially via river flooding usually at the peak of the rainy seasons when rivers may overflow their boundaries. The rural communities rarely build to block natural watercourses and most of their roads are built without drains. Rural communities in states such as Edo, Delta, Rivers, cross river, Kogi, Bayelsa, Benue, Lagos and Abia are often worse hit by floods and record casualties as in urban centres probably because of poor access to relevant information about the suspected movement of the flood. These rural communities experience very high crop loss due to these floods amongst other measurable and immeasurable losses.

Ambiental Environmental Assessment (undated) and Environmental Technology (2014) discussed five common types of flood - coastal (or surge), fluvial (or riverine or river), the pluvial flood, flash flooding and groundwater flooding. The coastal floods occur in areas that lie along the coast of a sea or large water body. The tides of the water when hit by hurricane push the water onshore causing coastal flooding. Coastal flooding can be minor (more like an erosion), moderate or major which poses a serious threat to life and property. The severity of coastal floods is determined by the strength, size, speed and duration of the storm as well as the onshore/offshore topography. The fluvial or river floods occur with excessive rainfall over a prolonged period, so much so it causes rivers to exceed their capacity. In the snowy region, large melting ice can also cause fluvial flooding. 
There are two types of riverine flooding viz flash flooding and overbank flooding. Overbank flooding is when the water rises over the edges of a river or stream. (www.intermap.com, 2014). Flash floods occur everywhere in the world but such is not the only flooding that occurs. Flash flood has an intense velocity of water occurring along an existing river channel without notice, hence it is very dangerous and destructive as it carries debris that can cause hurt. The severity of flash floods depends on precipitation and how saturated the area around the river is. Flash flood can be very dangerous as they are mostly unprepared for. The flow of water can move quickly; sweeping everything on its path. Floods occur when the water has nowhere to go. It was reported on International news in 2013 that flash floods kill over 200 people annually in the United States of America. The report analyzed that it takes six (6) inches of fast-flowing water to knock an adult off his feet and two (2) feet of water to float a car. (WCPC.com, 2018).

The third type of flood, the pluvial (or surface water) flood occur when heavy rain creates a flood. This flood is independent of any overflowing water body. Pluvial floods can occur even in areas far from water bodies. Pluvial floods can either be when intense rain overwhelms urban drainage systems, making them flow out or run-off when the earth fails to absorb rainwater. The Groundwater flood takes time to occur. As the rains fall overtime the ground gets saturated to the extent it can no longer absorb. This water rises and causes flooding. When the rains stop the flooding goes away over time, lasting even as long as months. (Environmental Technology, 2014).

Subhashree (2014) in his paper categorized flooding based on duration and location. By duration, he identified three types of flooding viz slow-onset flooding, rapid onset flooding and flash flooding. Under location, he identified coastal, arroyos, river and urban flooding. He was interested in urban flooding which he submitted is caused by a flash flood, coastal or river floods as well as a lack of drainage in urban areas,

\section{Flooding In Nigeria}

Nigeria is a country blessed with large coastal regions as well as mountainous highlands. These make her susceptible to all types of flooding during the rainy seasons. Communities in Nigeria have always experienced flooding in varying degrees. Many of these are periodic with the rainy season and often go unnoticed because they are not severe. These risks/hazards are unnoticed when the flood is low in volume and velocity. Prekeyi, Megbuwe and Adams (2015) reported that floodwaters from Cameroun entered Nigeria through rivers Benue and Niger on its way to the sea. This brought historic flooding in Nigeria in 2012 which was described as the worst in 50 years by a World Health Organization (WHO) report on www.reliefweb.int (2012). They reported that the flood remained in many communities in Nigeria's Niger delta till November 2012, even though Cameroun released their waters between July $2^{\text {nd }}$ and September 17th 2012. The floods were quite destructive. The water was slightly acidic with a $\mathrm{pH}$ of between 5.4 and 6.9. It also had the presence of heavy metals like chromium.

The 2012 Nigeria flooding severely affected the people of Edo North living around the river Niger. Hunters began to come home with animals only seen in the real wild forests till the floods got near and they realized the animals were displaced by the flood. It is important to note that these communities are left at the mercy of the river Niger and Benue; without the construction of any levee.

\section{Social and Economic Impact of Flooding in Nigeria}

Floods everywhere they occur leave behind negative tales of destruction and losses. Floods have great social consequences both for individuals and communities. Flooding has caused severe loss of lives and properties in developed and developing countries (Kwari, Paul and Shekarau 2015). Flooding is perceived as a hindrance that prevents Africa from achieving significant improvement in the lives of urban slum dwellers. (Action Aid,2006) Kwari et al (2015) revealed that Yola in Adamawa state was severely affected by flood in 2012 leading to deaths, loss of farmlands and inundation of schools. Socio-economic activities had to be put on hold. This led to losses running into millions of naira. In rural communities, the immediate effects of flood include loss of livestock, destruction of crops and health challenges. Office of the Queensland Chief Scientist, (undated) revealed that flooding can lead to disruption in the industry which further leads to loss of livelihoods and trauma experiences for the flood victims and their relatives. The destruction of infrastructure, clean water supply, electricity and transport as a result of a flood is widespread. The death of children through drowning caused by flooding is quite traumatizing. This was also reported about the Ibadan, Nigeria floods by Agbonkhese et al (2014) with a picture of four children under 10years who were drowned in the floods.

Lagos, Nigeria has also suffered socio-economically from flood menace. Ogunbiyi in Vanguard newspaper (2011) decried that Lagos being a coastal city has a peculiar flooding challenge. A lot of money had to be spent constructing new canals and drains and re-enforcing old ones. According to Agbonkhese et al (2014), the death from the 2011 flood was the reports of many Nigerian dailies. The Nation newspaper reported how a man and his two children got hospitalized following the collapse of a school fence on them following a flood. A man lost eight children at Ibadan while over 100 families were rendered homeless at Katsina. The story of the loss of 
human lives following floods is better heard than experienced. The report of Nkwunonwo (2016) showed that the July 2012 flood-affected 32 states (including Edo) in Nigeria. Farmlands were extensively destroyed leaving over 2million displaced person with economic loss placed at US\$16.9 billion. The 2012 flooding brought the heaviest financial loss and affected the largest number of persons in Nigerian flooding history. It affected 7,705,378 persons.

The flooding of Udaba, Anegbette, Osomegbe and Agbabu-Ekperi communities brought hardship to the people. In the 2012 flooding, many persons were displaced, buildings were submerged and farmlands were also submerged. Many were caught unprepared as it was the first time they experienced flooding. The communities were partially submerged for over two weeks. Many residents in the community never expected another flooding which came in 2018. This time their farms were larger and so the losses were more. See Appendix.

\section{Government Interventions on Flooding}

The hardship brought by flooding upon residents of various countries is usually beyond self-help efforts of the victims. It behoves both national and international governments and organizations to do the needful to ameliorate the sufferings of flood victims like victims of other disasters. Pettinger (2014) argued that since flooding affects many at the same time, flood protection or defences are public goods and so ought to be taken care of by governments using tax money. Therefore most expenses of flood control are borne by governments both nationally and internationally.

The Australian government has six government departments involved in handling issues on flooding by the Lake Victoria. Their roles in flood management include adherence to State flood policy; facilitating land use planning measure to reduce the future growth of flood risks and damages; support and assist communities to implement appropriate flood mitigation work; to ensure relevant flood information is available to all; provide financial assistance to victims and to develop State legislation, policy and standards for flood management amongst other functions. (www.floodvictoria.vic.gov.au, 2018)

In Nigeria, the Federal government intervention projects are meant to reduce the dangers associated with erosion and floods across the country. These projects fall under the Ecological Fund Office (pnmewsnigeria.com, 2018) in the office of the Secretary to the Government of the Federation. The Ecological Fund originally established in 1981 was intended to be an intervention facility established to address the multifarious ecological problems ravaging communities across Nigeria. (ecologicalfunds.gov.ng, 2019)

The Nigerian government also has the National Emergency Management Agency (NEMA) who usually do a needs assessment for an adequate government response to flooding. (www.reliefweb.int, 2018). The Nigerian Red Cross and other non-governmental organizations (NGOs) usually join in to assist flood victims in Nigeria. The government always moves to create camps for displaced persons, Over 33 camps were created in Kogi state in 2018 during the floods sent in by the rains. (Adesomoju, 2018). Some communities have permanent displacement camps which are maintained and used anytime the floods come in. One of such exists in Udaba community. (see Appendix).

Ebipade (2017) reported that Bayelsa state plans to approve funds for canalization to trap and empty floodwaters into a central drain at different locations. They also plan other interventions like sand filling of some communities to lift them above water level.

\section{The Study Area}

Udaba, Anegbette, Osomegbe and Agbabu-ekperi communities are all located in Etsako Central Local Government Area of Edo State, Nigeria. Etsako Central has an area of $660 \mathrm{~km}^{2}$ and a population of over 94,575 as reported in the 2006 census. The study communities are among the many other rural being ravaged by flooding for some years now. They are sited around the bank of the Rivers Niger and Orle river. The region has a fair share of rainfall hence their main cash crop is rice.

Destructive flooding was first experienced in the study area in 2012 when the Cameroons released excess waters from the Lagbo dawn into the river Benue and Niger. After the 2012 flooding, the communities did not experience any flooding up till 2018. The 2018 flooding was due to a shift in rainfall patterns as the Nigeria metrological Agency (NiMet) warned would cause floods. This shift they attributed to climate change. (Vanguard, 2018). NiMet also predicted the 2012 floods which ran true in the study area bringing much havoc to farmlands, houses and people we rendered homelessly. NiMet and the Nigeria Hydrological Services Agency (NIHSA) were reported to have identified and presented to the public the flashpoints of the 2018 flooding. However, most of the residents claimed the 2018 flood came to them unprepared.

\section{Methodology}

The study utilized primary data obtained through a questionnaire, personal observation and interviews with the residents of the study communities. The population consisted of all persons whose farmland/properties were submerged by flood. Community leaders were interviewed to find out of any government intervention during 
the flooding period. People whose farmlands and homes were submerged in these communities are about 13,800 which constitute the study population. A simple random sampling technique was used to select 1000 respondents which form the sample size for the study.

\section{Research Questions}

In guiding this study, the following research questions were raised

a. How has the flood affected the economic life of the people of the study communities?

b. How has the flood affected the social life of the people of the community?

c. How far has the government helped in alleviating the sufferings of these people?

d. What do the people think can be done as a permanent solution to flooding in their communities?

\section{Hypotheses}

$\mathrm{H}_{01}$ : There is no significant difference in the economic life of the people after the flood.

$\mathrm{H}_{02}$ : There is no significant difference in the social life of the people after the flood.

$\mathrm{H}_{03}$ : There is no significant difference made by government help during the flooding

\section{Questionnaire Instrument}

The questionnaire consists of 27 items structured by the researchers to elicit information from the respondents on the socio-economic impact of flooding in their communities. A four-point Likert scale was used: strongly agree (SA), Agree (A), strongly disagree (SD) and disagree (D). the construct validity of the instrument was validated using Principal component analysis (PCA) to determine the abstructure properties of each of the scales integrated into the questionnaire. The split-half procedure was adopted in determining the reliability of the instrument. SPSS was used to arrange the data and analysis.

\section{Results and discussion of findings}

After data analysis, the results as presented in table 1 to 6 in the appendix emerged. Table 1 shows the demography of the respondents. We had 564(56.4\%) male respondents and 436(43.6\%) were female. Four locations were used for the study disaggregated into Udaba 270 (27\%), Osomegbe 223 (22.3\%), Anegbette 206 (20.6\%) and Agbabu-Ekperi 301 (30.1\%). The table also revealed that $188(18.8 \%)$ of the respondents were students; 583 (58.3\%) were farmers; 38 (3.8\%) were into fishing; 108 (10.8\%) were into various types of trading; $9(0.9 \%)$ were civil servants while the remaining $74(7.4 \%)$ were in other types of occupations.

Item 1 on table 2 revealed that $601(60.1 \%)$ respondents suffered the loss of their cultivated farmlands; 369 $(36.1 \%)$ suffered pollution of their source of water while $38(3.8 \%)$ suffered the loss of a loved one. Item 2 on table 2 showed that $183(18.3 \%)$ respondents earned less than N100,000 during the farming seasons; 180 (18\%) earned between N100,000 and N200,000; 541 (54.1\%) earned between N200,000 and N300,000 while 98 (9.6\%) earned between N300,000 and N400,000 before the floods. However, following the flood $643(64.3 \%)$ earned less than N100,000 and 357 (35.7\%) earned between N100,000 and N200,000. This reveals the huge financial loss the villages must have suffered following the loss of their cultivated farmlands as shown in the pictures in the appendix.

Of the 1000 respondents, table 2 item 4 revealed that $200(20 \%)$ stayed in the internally displaced persons (IDP) camp. Of the remaining 800, 437 (43.7\%) and 363 (36.3\%) stayed in their homes and moved to dry parts of their communities respectively.

On feeding, item 5 on table 2 revealed that $512(51.2 \%)$ of the respondents fed by personal efforts as many had to harvest their premature crops which were not sellable to avoid 100\% loss (picture in appendix) 488 $(48.8 \%)$ were fed by government aid. It was somewhat worthy of note that none of the respondents received help from private institutions/individuals outside the community as happens in the developed world. This is probably due to low media coverage of the devastation faced by the people of Udaba, Osomegbe, Anegbette and Agbabu-Ekperi.

Table 3 shows the means and standard deviation of the Likert scale questions in the questionnaire. A means score of 2.5 was considered as agreed. The mean scores ranged between 2.25 and 3.31 with very low standard deviations.

Items 1 and 2 on table 3 showed a mean of 3.05 (S.D. $=0.656$ ) and 3.12 (S.D. $=0.795$ respectively indicating that the flooding of these communities was caused by heavy rains and overflow of the River Niger in their vicinity.

Item 3 indicated that they received help from the government. This was reflected in a mean score of 2.76 $(\mathrm{SD}=0.973)$. The responses on item 4 with a mean score of $2.37(\mathrm{SD}=0.881)$ also revealed that the level of information dissemination by the government regarding the movement of the flood was poor. However, table 6 showed a rejection of the null hypotheses $\mathrm{H}_{\mathrm{O} 1}$ that there is no significant difference made by the assistance offered the people by the government. The F-statistics calculated gave 48.128 as against the tabulated F statistic 
of 3.1161 which was statistically significant at the $5 \%$ level of significance. Item 7 (means score $=2.63, \mathrm{SD}=$ 0.771 ) also agreed that the flood increased government presence in the communities.

From item 5 (mean score of 3.28) and 6 (means a score of 3.28), the responses revealed that the flood had negative effects on the finances and social life respectively. The ANOVA results in table 5 and 6 showed rejection of the null hypothesis of no difference in the economic and social life of the people respectively. The F-statistic calculated was statistically significant in both hypotheses at the $5 \%$ level of significance. However, item 9 on table 3 showed that the flood increased cooperation among the people in different villages. A mean score of $3.10(\mathrm{SD}=1.126)$ indicated general agreement of the increased cooperation.

Finally, items 11a to $11 \mathrm{f}$ on table 3 revealed the control measure for the flood from the respondents view items $11 \mathrm{a}, 11 \mathrm{c}, 11 \mathrm{e}$ and $11 \mathrm{f}$ having a mean score of $3.31,2.57,2.53$ and 2.80 respectively suggest that to control flooding they recommended:

a. Dam the river

b. Construct reservoir for the excess water which can be used for irrigation in the dry season.

c. Use sand bangs

d. Use higher foundations in buildings.

This study will help to draw more attention to the issue of flooding in Udaba, Osomegbe, Anegbette and Agbabu-Ekperi. Flooding here is not annual as the first happened in 2012 while the second and last so far was in 2018 .

\section{Conclusion and recommendation}

Flood has many negative and costly effects not only in cities or urban centre but also in rural communities in Nigeria. The pains of flooding as experienced by the people of Udaba, Osomegbe, Anegbette and AgbabuEkperi are quite much even as experienced first hand by the researchers. Urgent steps need to be taken as recommended below.

Based on the findings, this study recommends amongst others that

a. there be adequate and early information sent to communities where there is a likelihood of flooding. Such information must be carried by government agencies directly to the kings of such communities who will use their best methods to disseminate the information.

b. there is an urgent need for the government to begin to look into possible dredging of the river or the construction of reservoirs which are capital intensive.

\section{Acknowledgement}

The researchers acknowledge with gratitude the funding for this entire research work provided by the Tertiary Education Fund (TETFUND), Nigeria.

\section{References}

Action Aid (2006). Climate change, urban flooding and the rights of the urban poor in Africa. A report by Action Aid International.

Adesomoju, A. (2018). FG declares flooding as a national disaster in four states. Retrieved $14^{\text {th }}$ February 2019 at http://punchng.com/.

Adewale, P.O; Siyanbola, A.B. and Olayemi, A.O. (2015). Climate change and flood disaster management in Nigeria urban centres: The Architects Perspective. International Journal of Sustainable Energy and Environmental Research. 4(9): 64-72.

Agbonkhese, O.; Agbonkhese, E.G; Aka, E.O; Joe-Abaya, J.; Ocholi, M. and Adekinle, A. (2014). Flood menace in Nigeria: impacts, remedial and management strategies. Civil and Environmental Research. 6(4);32-40.

Aliyu, H.I. and Suleiman, Z.A. (2016). Flood menace in Kaduna metropolis: Impacts, remedial and management strategies. Science World Journal. 11(2):16-22.

Ambiental Environmental Assessment (undated). Types of flood and flooding impact. Retrieved $13^{\text {th }}$ February 2019 at https://www.ambiental.co.uk/types-of-flood-and-flooding-impact/.

B-Air (2018). What causes floods? Top 8 common causes of flooding. Retrieved $13^{\text {th }}$ February 2019 at https://b-air.com/2018/02/common-causes-of-flooding/.

Ebipade, A. (2017). Bayelsa strategizes to rescue communities from flooding. Retrieved $14^{\text {th }}$ February 2019 at www.tribuneonline.ng.com/108066/.

Efobi, K and Anierobi, C. (2013). Urban flooding and vulnerability of Nigerian cities: a case study of Awka and Onitsha in Anambra State, Nigeria. Retrieved 12th February 2019. at www.iiste.org.

Elenwo, E.I. (2015). Socio-economic impacts of flooding on the residents of Port Harcourt metropolis in Rivers state, Nigeria. National resources. 6(2):1-8.

Elrha.org (undated). Government intervention for flood recovery of small businesses. Retrieved $14^{\text {th }}$ February 2019 at https://www.elrha.org/project-blog/ 
Emeribeole, A.C. (2015). Managing food disasters in Nigerian cities: issues and strategies towards meeting the challenges in the modern world. (a case study of Owerri metropolis, Imo state, Nigeria). FIG working week 2015 From the wisdom of the ages to the challenges of the modern world, Bulgaria.

Environmental Technology (2014). What are the different types of floods? Retrieved $13^{\text {th }}$ February 2019 . at https://www.envirotech-online.com/news/water-wastewater/9/

Etuonovbe, A.K. (2011). The devastating effect of flooding in Nigeria. Hydrography and Environment TS06J, Epworth, Zimbabwe.

Flood victoria (2018). Flood victoria. Role of State Government. Retrieved 14 ${ }^{\text {th }}$ February 2019 at www.floodvictoria.vic.gov.au/prepare-prevent/.

Grant, K (2017). A look at the deadliest floods in history as Harvey continues to drench Texas. Retrieved $12^{\text {th }}$ February 2019 at https://www.the street.com/story/14285968/1/.

Hewitt, K. \& Sheehan, L. (1969). A pilot survey of global natural disasters in the past twenty years. Natural Hazards Research Working paper No. 11, University of Toronto, Toronto.

Ijigah, E.A and Akinyemi, T.A. (2015). Flood disasters: an empirical survey of causative factors and preventive measures in Kaduna, Nigeria. International Journal of Environment and Pollution Research. 3(3)'53-66.

Kwari, J.W; Paul, M.K. and Shekarau, L.B. (2015). The impacts of flooding on socio-economic development and agriculture in northern Nigeria: A case study of 2012 flooding in Yola and Numan Areas of Adamawa State, Nigeria. International Journal of Scientific \& Engineering Research. 6 issues 7.

Leadership Editors (2018). Addressing issues of flood and erosion. Retrieved 24 ${ }^{\text {th }}$ October 2018 at http://leadership.ng/2018/09/07/addressing-issue-of-flood-and-erosion/.

Ndujihe, C (2018). Rains of fury: Nigeria loses 141 lives to a rainstorm, flood in 2018. Retrieved on $3^{\text {rd }}$ February 2019 at http://www.vanguardngr.com/2018/01/rains-of-fury-nigeria-looses-141-lives-to-rainstorm-floodin-2018/.

Nkwunonwo, U.C. (2016). A review of flooding and flood risk reduction in Nigeria. Global Journal of Human Social Science, Geography, Geo-science, Environmental Science and Disaster Management. 16 issue 2 version 1.0 .

Nkwunonwo, U.C.; Malcolm, W. and Brian, B. (2015). Flooding and flood risk reduction in Nigeria: Cardinal gaps. Journal of Geography \& Natural Disasters. 5:136.

Nwigwe, C, and Emberga, T.T. (2014). An assessment of the causes and effects of flood in Nigeria. Standard Scientific Research and Essays. 2(7):307-315.

Office of the Queensland Chief Scientist (undated). What are the consequences of the flood. Retrieved on $13^{\text {th }}$ February 2019 at https://www.chiefscientist.qld.gov.au/publications/

Oriole, E.O. (1994). Strategies for combating urban flooding in a developing nation: a case study from Ondo state, Nigeria. The Environmentalist. 14(1):57-62.

Patil, S.A. and Patil, S.S. (undated). Socio-economic impacts of flood disaster in upper Krishna basin: A case study of village Pundi (Tal. Palus, Dist. Sangli, Maharashtra). Proceedings of National Conference on Population, Environment and Tourism. Pg. 19-25.

Pattinger, T. (2014). Flood defences as a public good. Retrieved 14 ${ }^{\text {th }}$ February 2019 at www.economichelp.org/blog/9960/.

PM News (2018). Nigerian Government intervention projects will reduce erosion, flood. Retrieved $14^{\text {th }}$ February 2019 at https://www.pmnewsnigeria.com.

Prekeyi, T.F; Megbuwe, P. and Adams, O.G. (2015). Some aspects of historic flooding in Nigeria and its effect on some Niger-Delta Communities. American Journal of Water Resources. 3(1):7-16.

Punchng.com (2018). 12 killed as floods hit southwest France. Retrieved 12 $2^{\text {th }}$ February 2018 at https://punchng.com/.

Slaughter, A and Odume, N. (2017). Why flooding in Nigeria is an increasingly serious problem. Retrieved $24^{\text {th }}$ October 2018 at http://the conversation.com/why-flooding-is-an-inceeasingly-serous-problem/82272/.

Subhashree, N. (2014). Addressing Delhi's urban flooding problem. University School of Architecture and Planning Research Paper 2013-14.

Vanguard newspaper (2018). The shift in rainfall pattern may cause floods in 2018, NiMet warms. Retrieved $13^{\text {th }}$ February 2019 at https://www.vanguardngr.com/2018/07/.

Vanguard Newspapers (2011). Combating the menace of flooding in Lagos. Retrieved $24^{\text {th }}$ October 2018 at http://www.vanguardngr.com/2011/07/.

Wikipedia (2018). 2018 Japan floods. Retrieved $12^{\text {th }}$ February 2019 at https://en.wikipedia.org/wiki/2018-japanfloods/.

WHO (2012) Public health risk assessment and interventions - flooding disaster: Nigeria. Retrieved 14th February 2019 at https://reliefweb.int/report/nigeria/. 
Table 1: Demography of the respondents

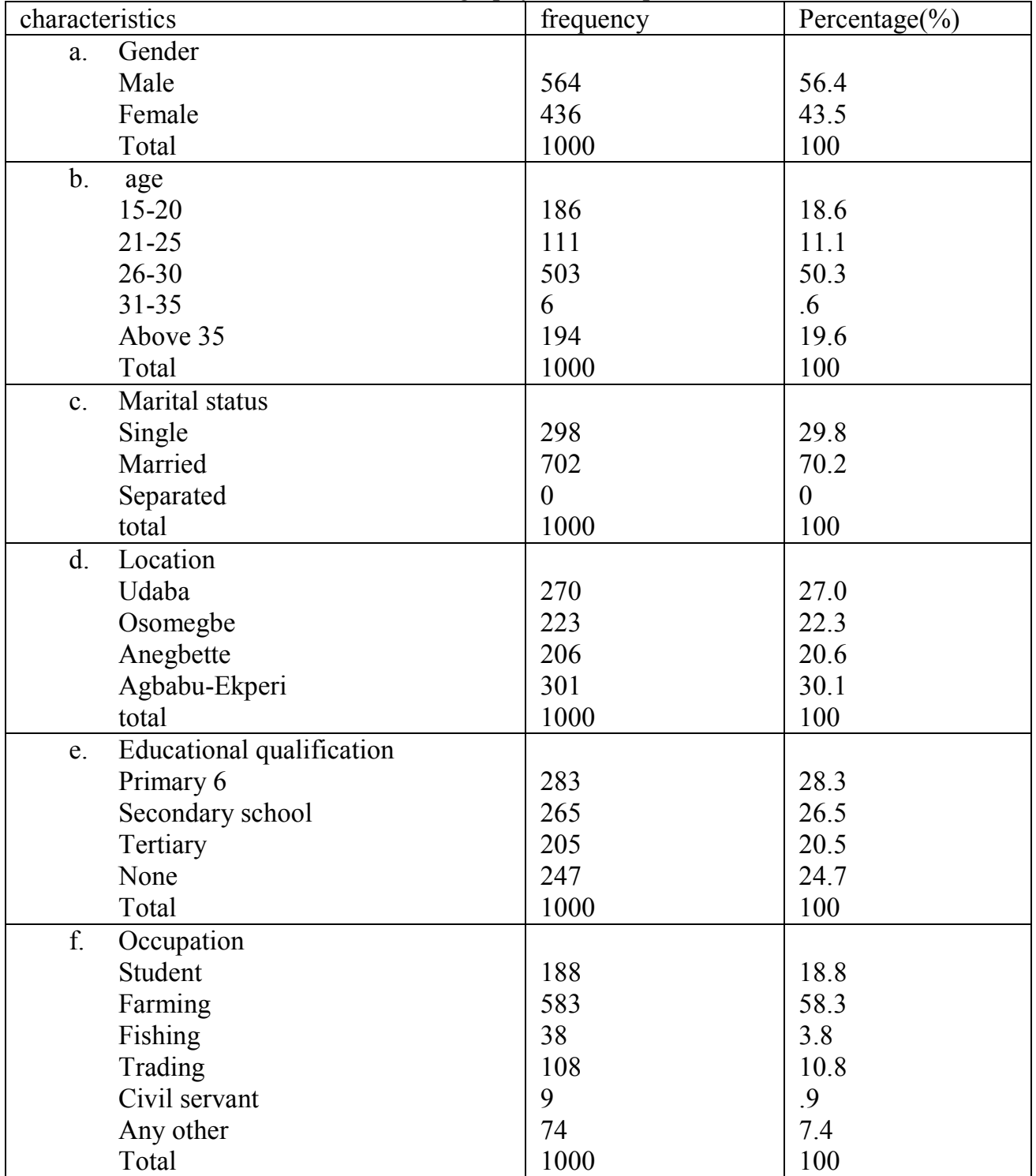


Table 2

\begin{tabular}{|l|l|l|}
\hline Question & freq & percent \\
\hline 1. if yes, what type of loss & & 361 \\
Water polluted & 601 & 60.1 \\
Farmland & 38 & 3.8 \\
Loss of life & 183 & 18.3 \\
\hline 2. How much income did you make before the flood? & 180 \\
Less than 100k & 541 & 54.1 \\
100-200k & 96 & 9.6 \\
200-300k & & \\
$300-400 k$ & 643 & 64.3 \\
\hline 3. how much income did you make while the flood lasted & 357 & 35.7 \\
Less than 100k & & \\
$100-200 k$ & 200 & 20.0 \\
\hline 4 where did you stay during the floods? & 437 & 43.7 \\
Camp & 363 & 36.3 \\
My home & & \\
The dry part of my community & 488 & 48.8 \\
\hline 5 How did you get food during the flood? & 512 & 51.2 \\
\hline Govt aid & \\
\hline Personal & & \\
\hline
\end{tabular}

Table 2: Means and standard deviations of Likert scale questions

\begin{tabular}{|c|c|c|c|c|}
\hline & $\mathrm{N}$ & Mean & Std. Dev & Remark \\
\hline 1. The flood was caused by heavy rains. & 1000 & 3.05 & .656 & Agreed \\
\hline 2. The flood was caused by the overflow of the river & 1000 & 3.12 & .795 & Agreed \\
\hline $\begin{array}{l}\text { 3. The help offered by government agencies during the flood is } \\
\text { adequate. }\end{array}$ & 1000 & 2.76 & .883 & Agreed \\
\hline $\begin{array}{l}\text { 4. The level of information dissemination by the government } \\
\text { regarding the movement of the flood was good. }\end{array}$ & 1000 & 2.37 & .881 & disagree \\
\hline $\begin{array}{l}\text { 5. The flood has negative effects on our finances/sources of } \\
\text { income }\end{array}$ & 1000 & 3.28 & .926 & Agree \\
\hline $\begin{array}{l}\text { 6. The flood has negative effects on our social life in this } \\
\text { community. }\end{array}$ & 1000 & 3.28 & .935 & Agree \\
\hline 7. The flood has increased government in our community & 1000 & 2.63 & .771 & Agree \\
\hline 8. Life in the displacement camp is fair enough & 1000 & 2.25 & .877 & disagree \\
\hline $\begin{array}{l}\text { 9. While the floods lasted, the cooperation among the villagers } \\
\text { improved. }\end{array}$ & 1000 & 3.10 & 1.125 & agree \\
\hline $\begin{array}{l}\text { 10. After the floods, I am better prepared to do better in case of } \\
\text { another flooding. }\end{array}$ & 1000 & 3.10 & .773 & agree \\
\hline 11a. For flood control, dam the river & 1000 & 3.31 & .719 & agree \\
\hline 11b. for flood control dredge the river & 1000 & 2.48 & 1.141 & disagree \\
\hline $11 \mathrm{c}$ construct reservoir for the excess water & 1000 & 2.57 & .947 & agree \\
\hline 11d Relocate people early to higher ground & 1000 & 2.27 & .754 & disagree \\
\hline 11e. Use sand bags & 1000 & 2.53 & .837 & agree \\
\hline 11f. Use higher foundation & 1000 & 2.80 & .956 & agree \\
\hline
\end{tabular}


Table 4

\begin{tabular}{|l|r|r|r|r|}
\hline & $\begin{array}{c}\text { Sum of } \\
\text { Squares }\end{array}$ & df & \multicolumn{1}{c|}{$\begin{array}{c}\text { Sean } \\
\text { Square }\end{array}$} & F \\
\hline Sig. \\
flood?
\end{tabular}

Table 5

While the floods lasted, the cooperation among the villagers improved.

\begin{tabular}{|l|r|r|r|r|r|}
\hline & Sum of Squares & df & Mean Square & F & Sig. \\
\hline Between Groups & 511.149 & 3 & 170.383 & 225.535 & .000 \\
Within Groups & 752.442 & 996 & .755 & & \\
Total & 1263.591 & 999 & & & \\
\hline
\end{tabular}

Table 6

the help offered by government agencies during the flood is adequate.

\begin{tabular}{|l|r|r|r|r|r|}
\hline & Sum of Squares & \multicolumn{1}{c|}{ df } & Mean Square & F & Sig. \\
\hline Between Groups & 98.684 & 3 & 32.895 & 48.128 & .000 \\
Within Groups & 680.752 & 996 & .683 & & \\
Total & 779.436 & 999 & & & \\
\hline
\end{tabular}


Picture Appendix
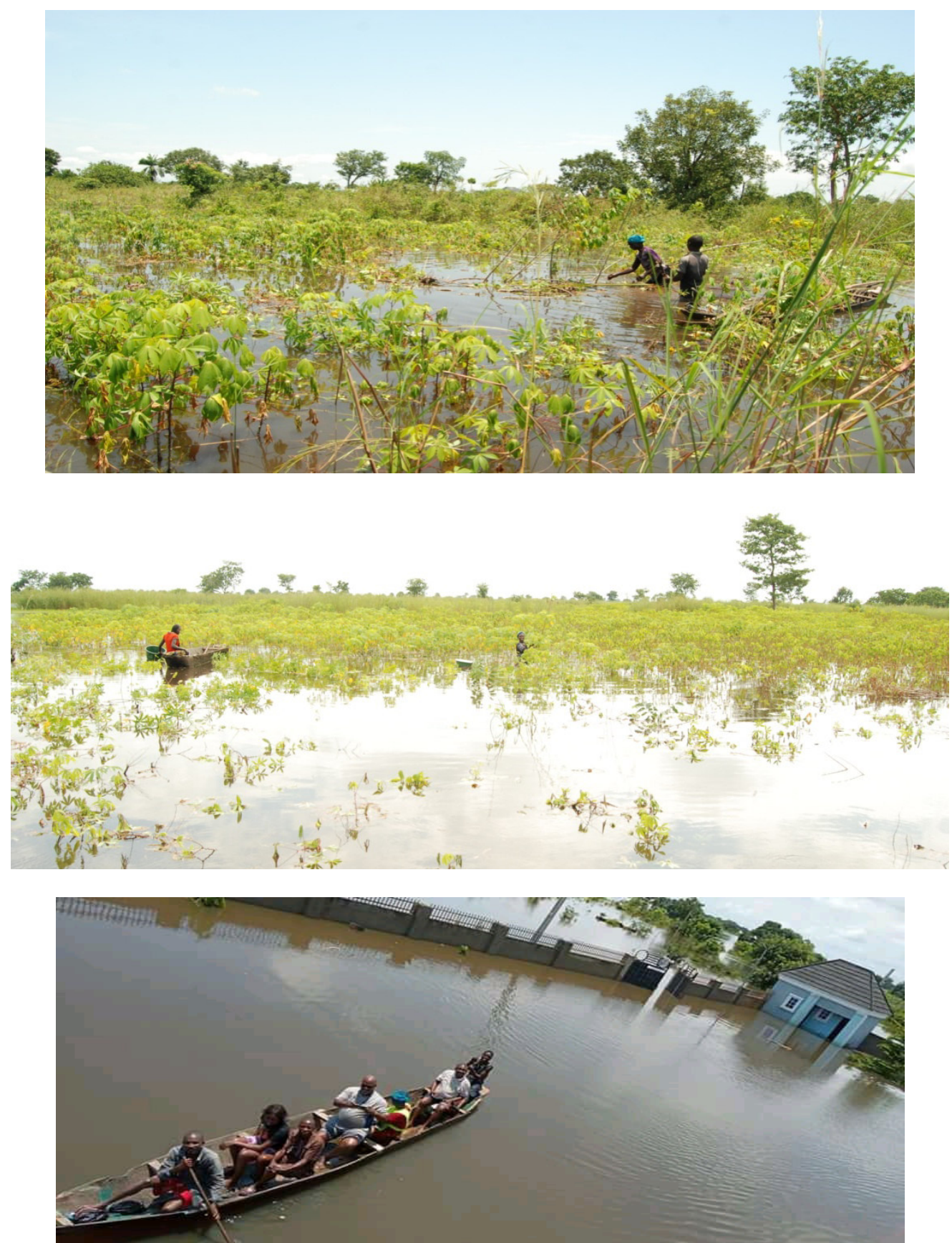

Flooded fenced compound at Udaba 

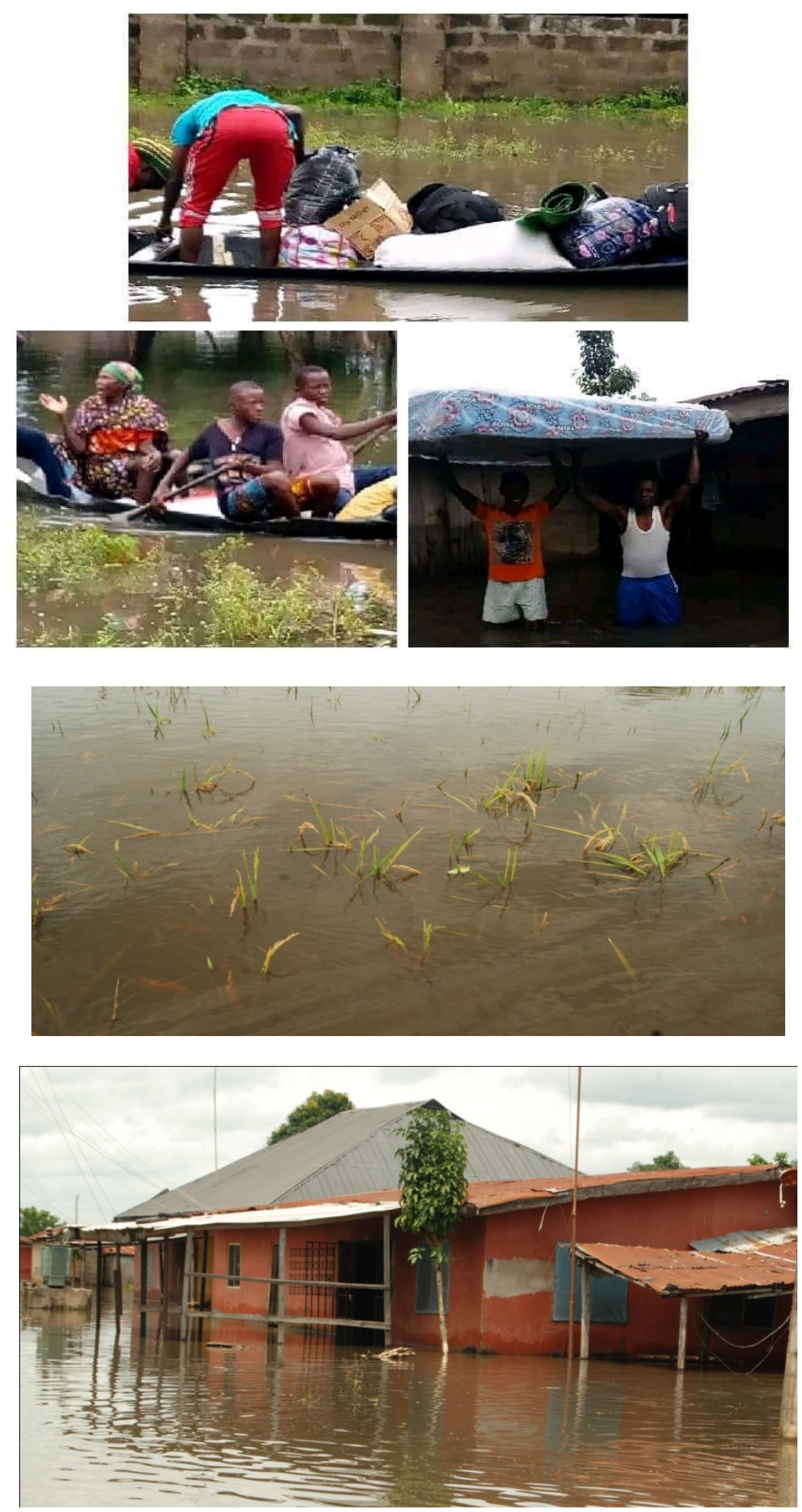

The King of Udaba's palace overtaken by the 2018 flood 

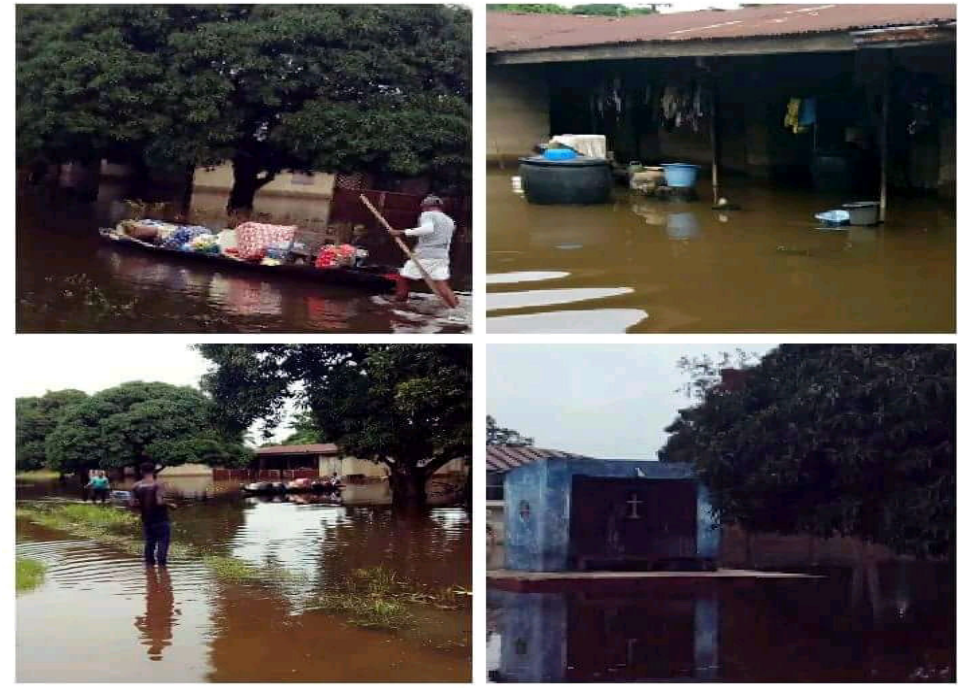

Flooding at Agbabu community

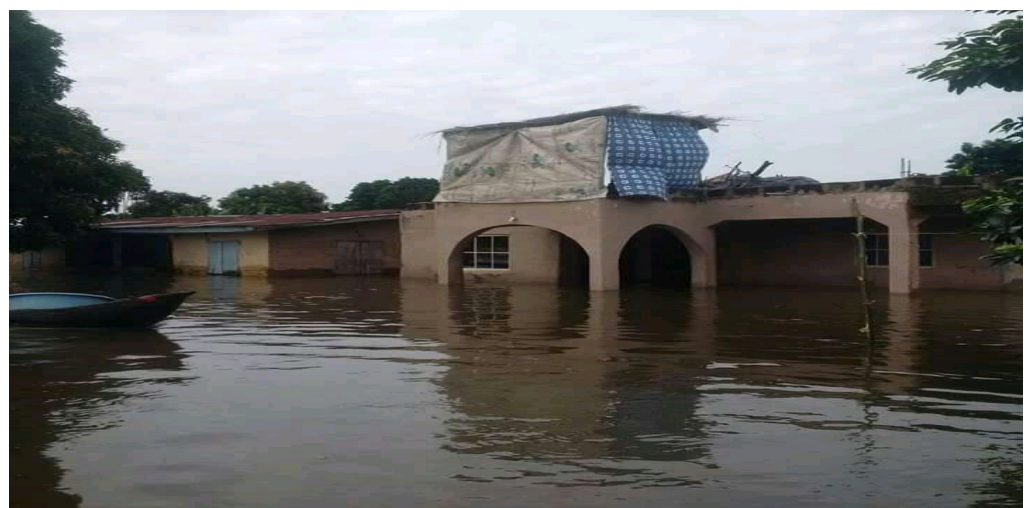

Submerged home at Agbabu community 2018

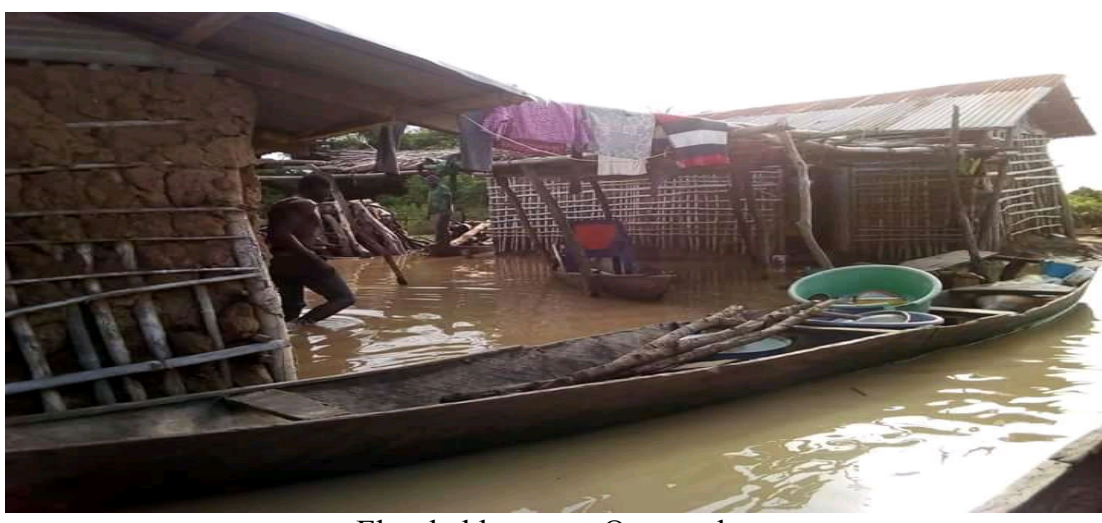

Flooded house at Osomegbe 


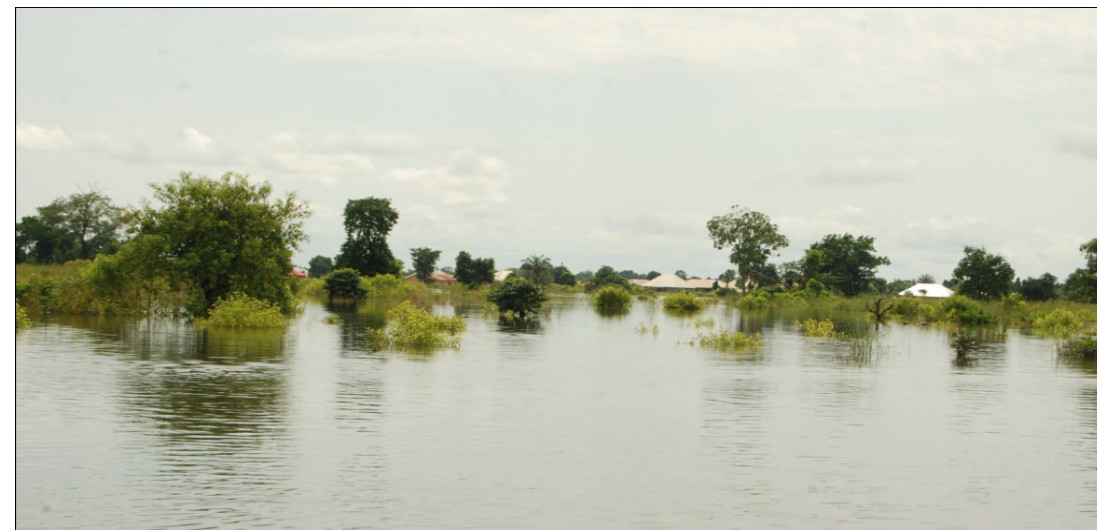

Submerged farmland at Udaba

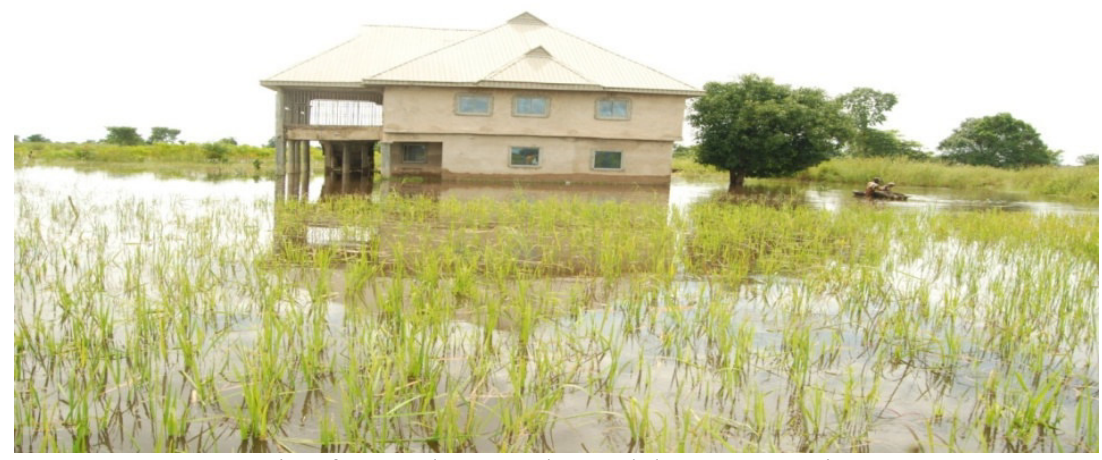

Rice farm submerged at Udaba Community

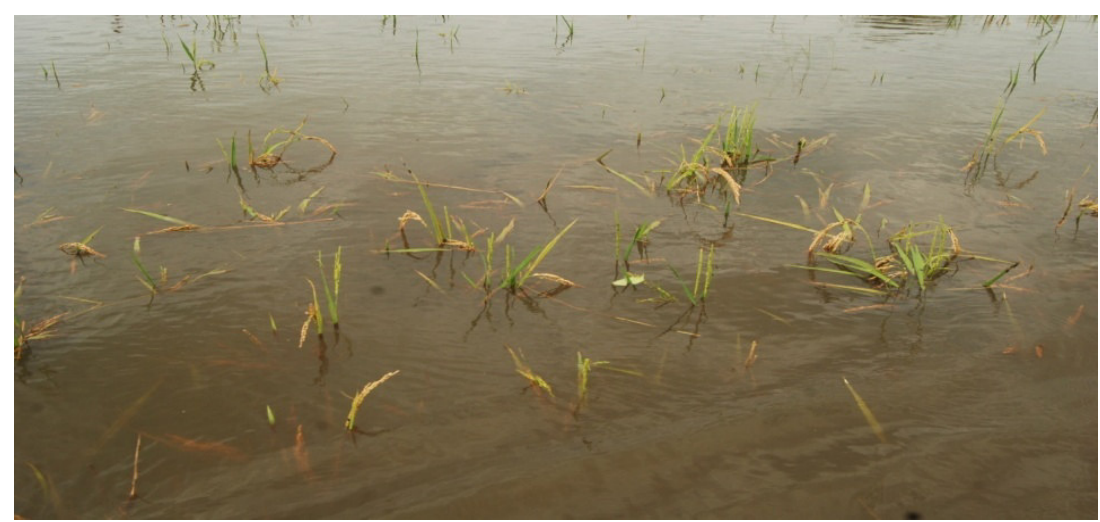

Submerged rice farm at Osomegbe

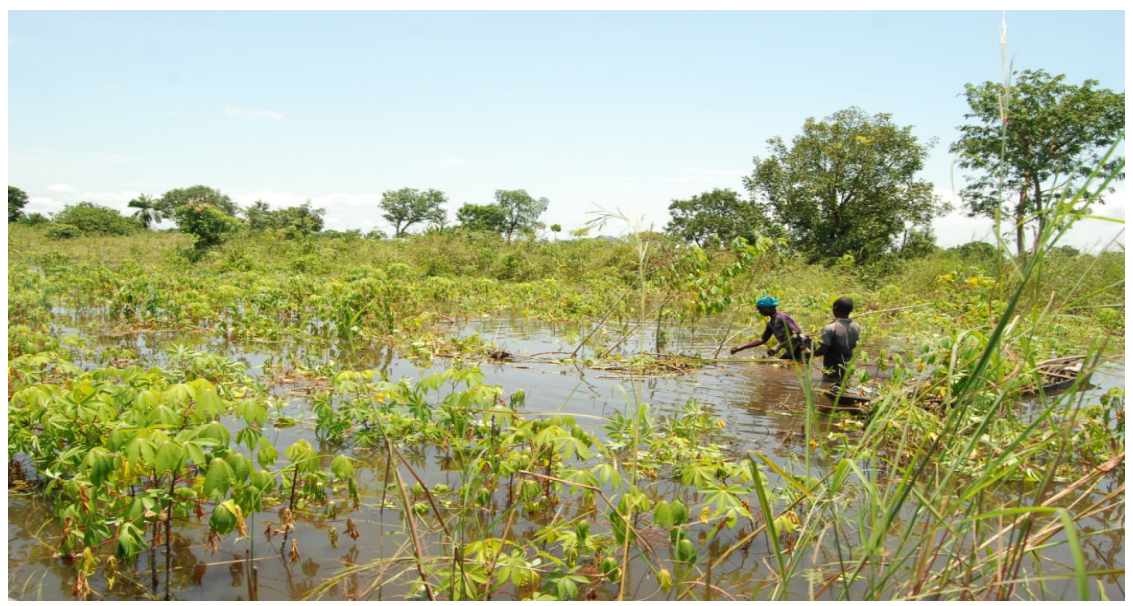

Submerged cassava farm at osomegbe 


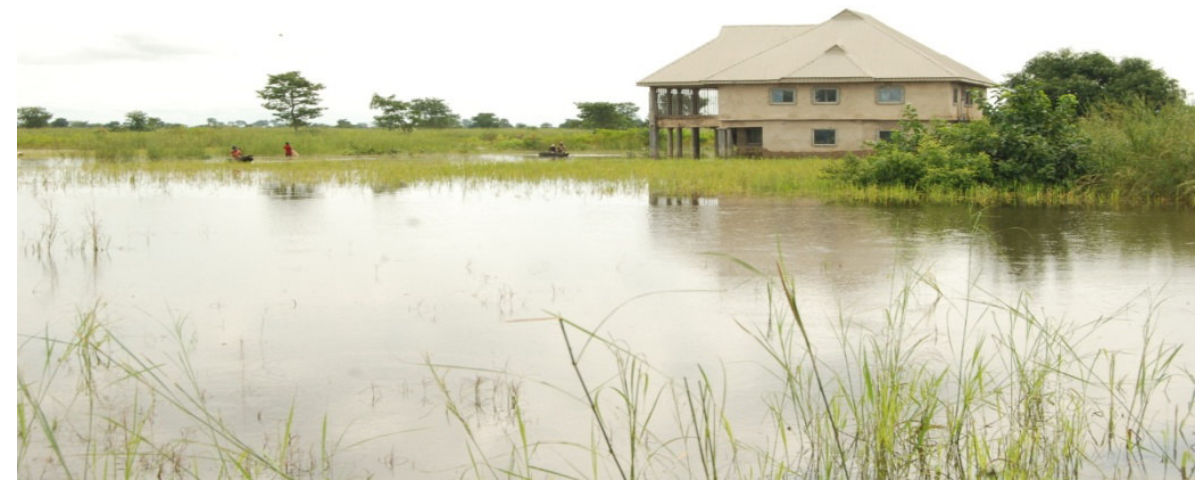

Flooded street at Udaba
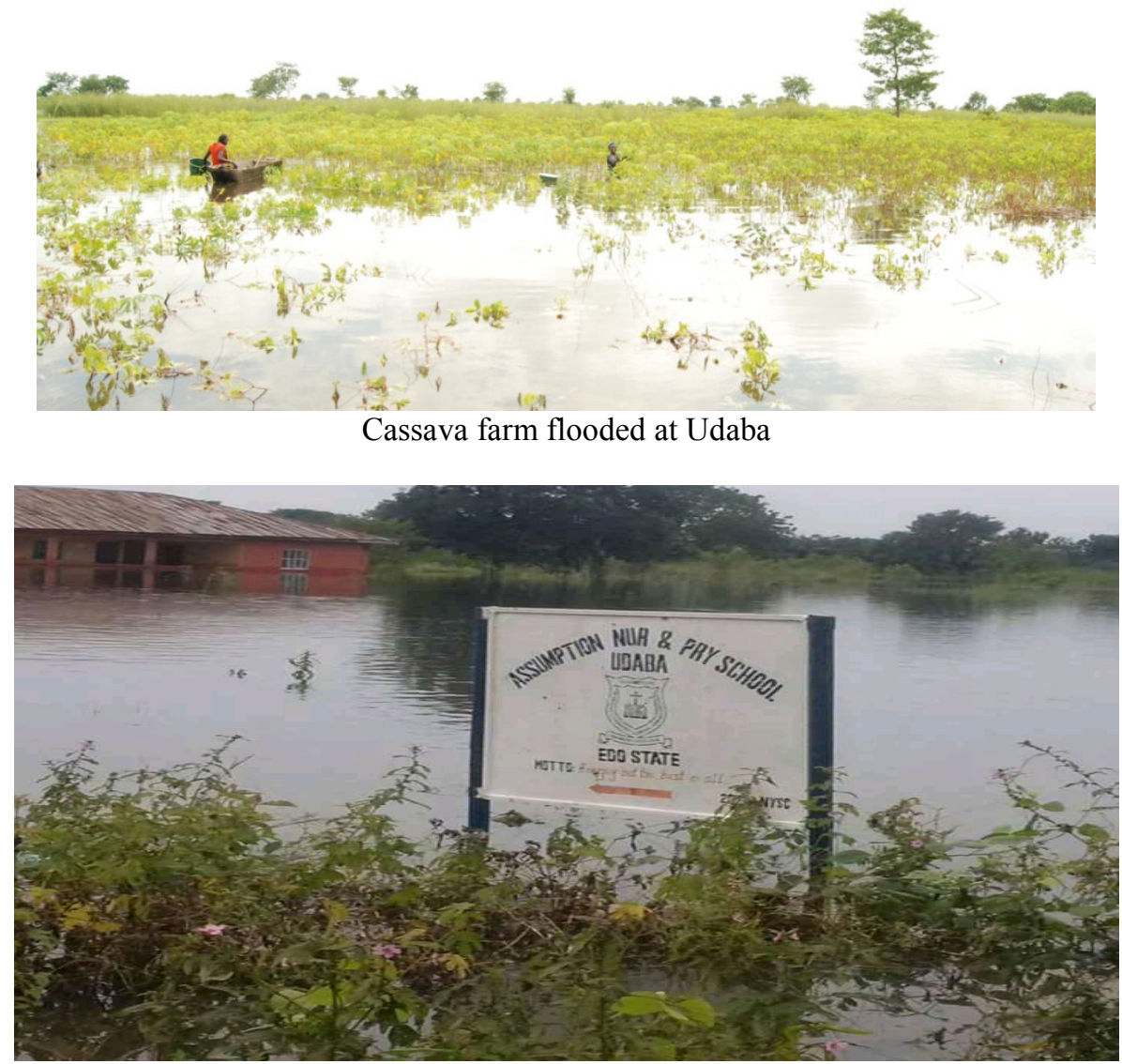

Private school submerged at Udaba by the 2018 flood

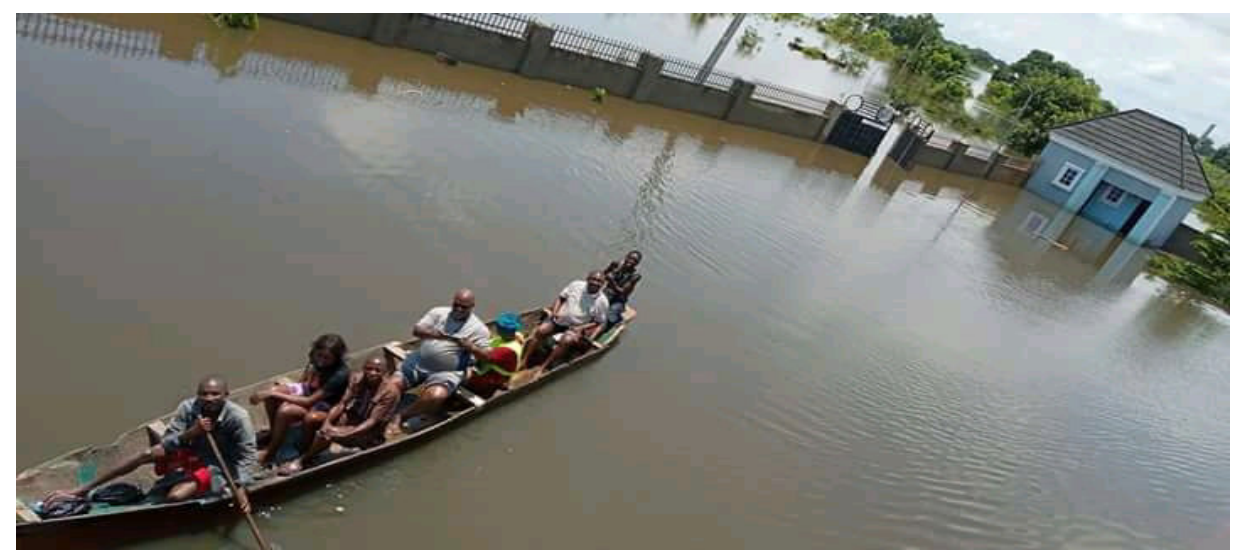

Flooded fenced compound at Udaba 


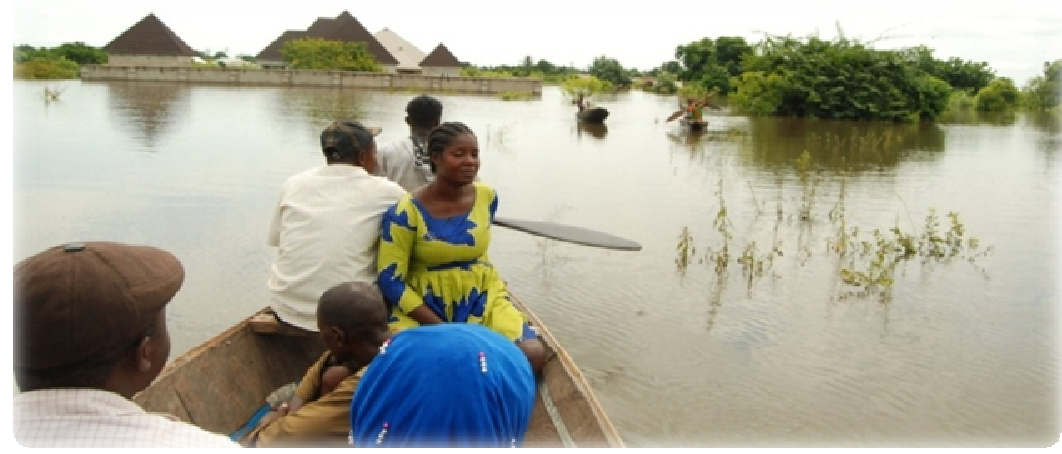

Transportation by Canoe along submerged streets in Udaba

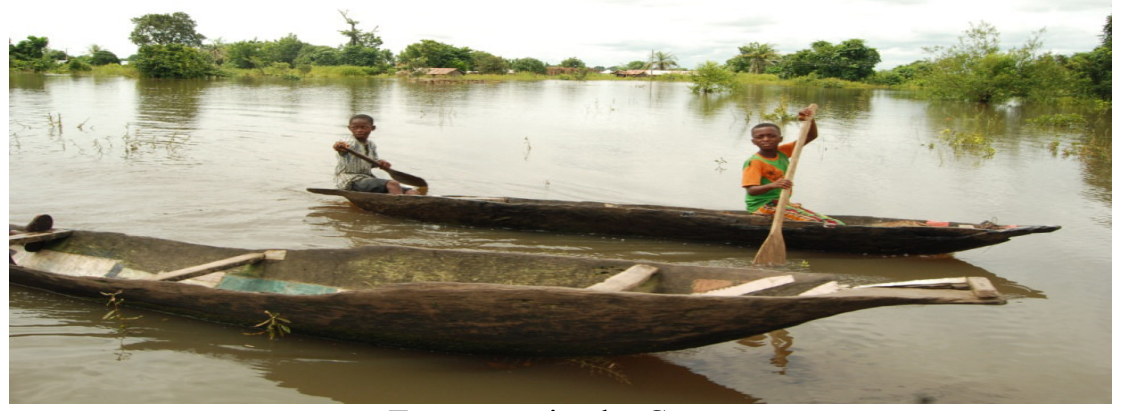

Transportation by Canoe

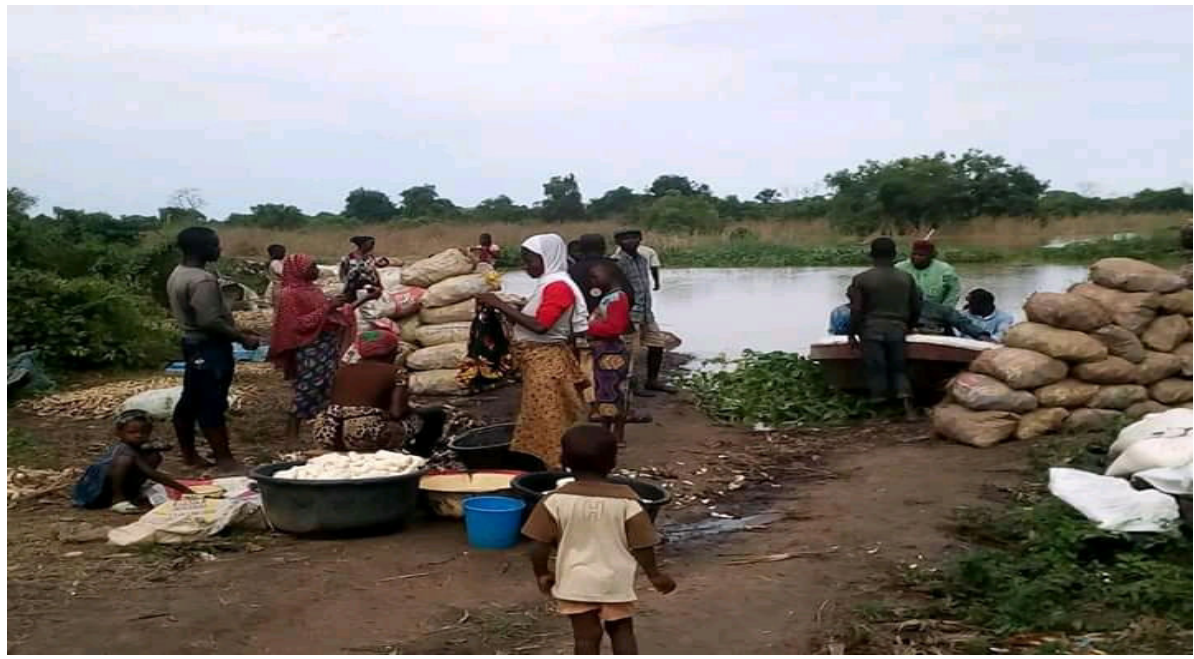

Premature cassava waiting for canoe transport at Osomegbe

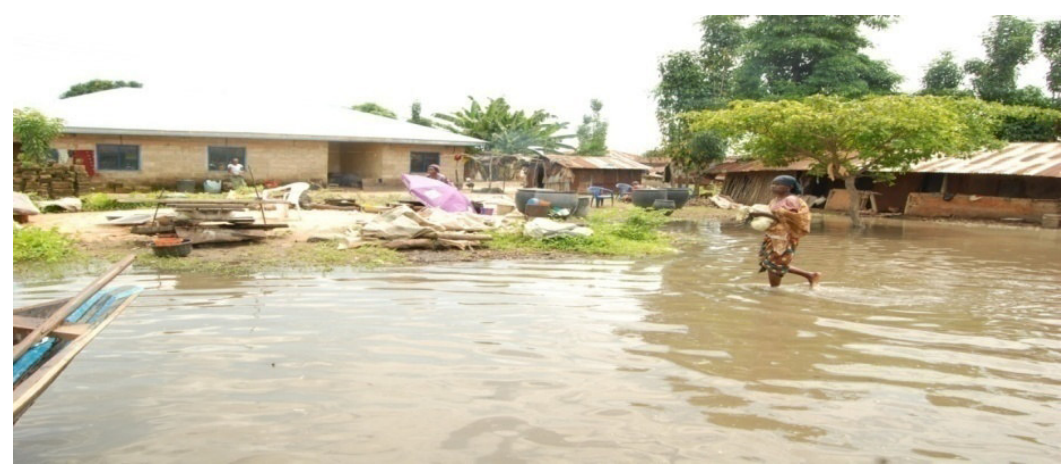

Small remaining dry land at Udaba 


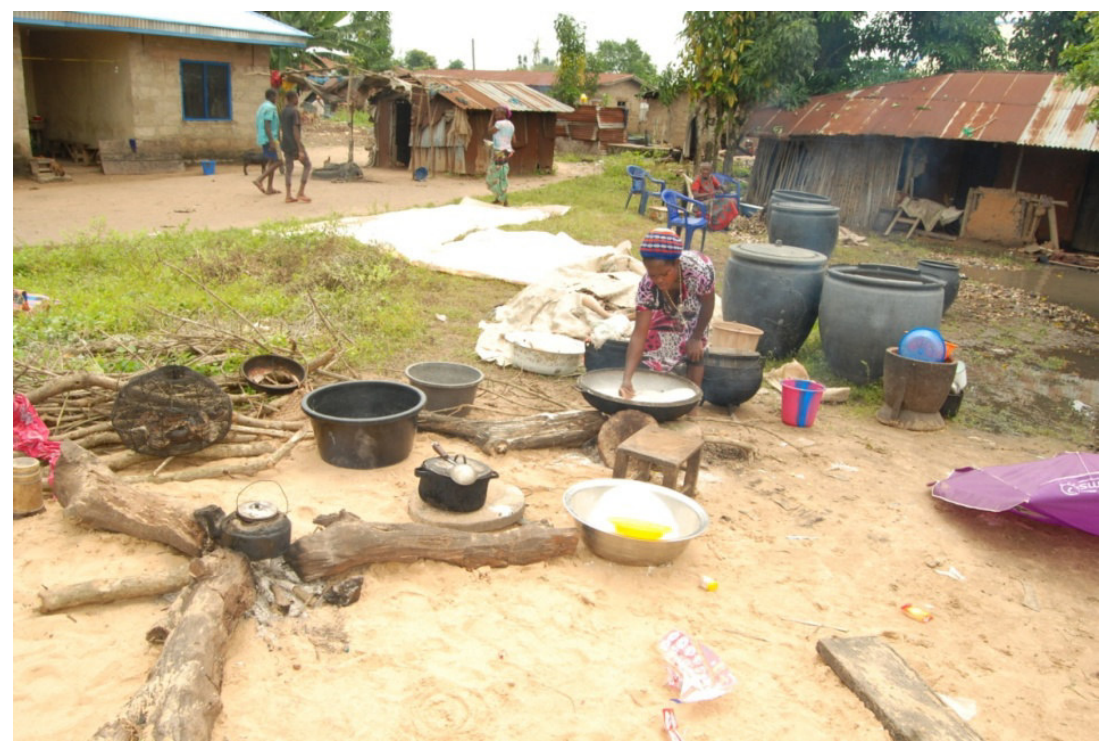

Dry space at Udaba for cooking

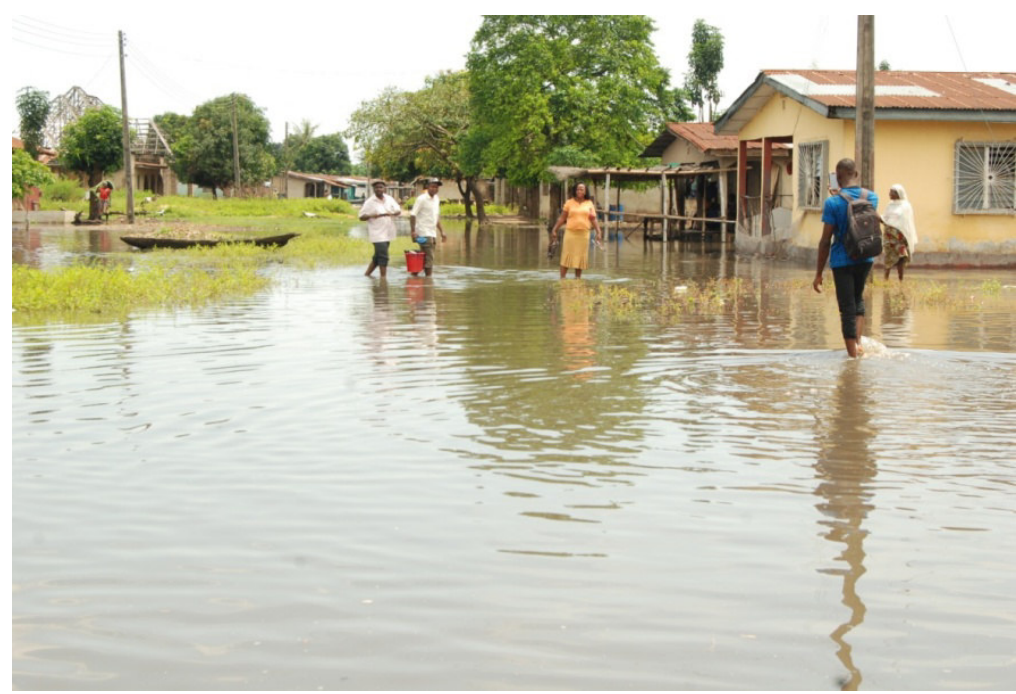

Flooded street at Osomegbe

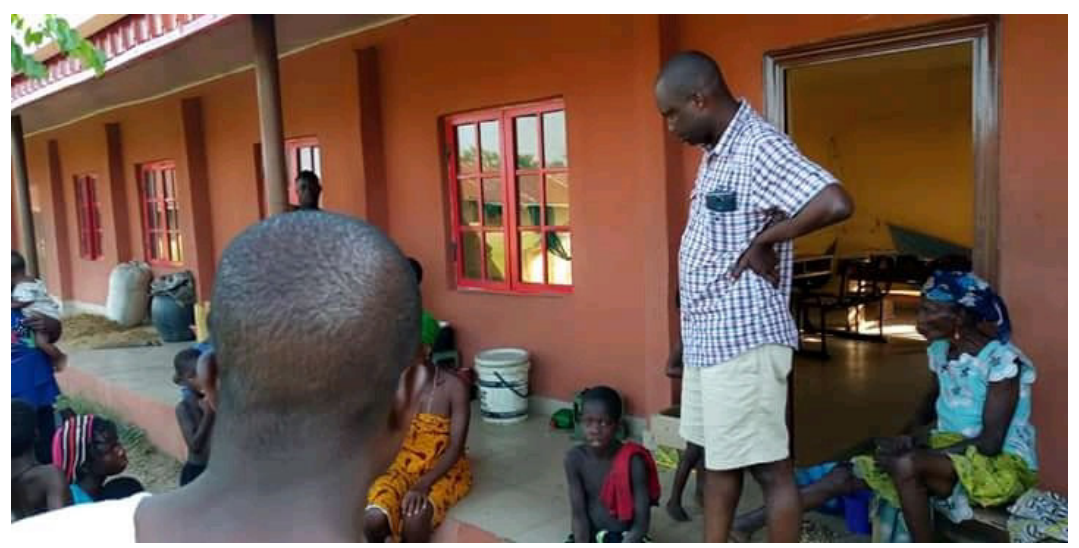

Osomegbe people displaced by flood residing at a government school 


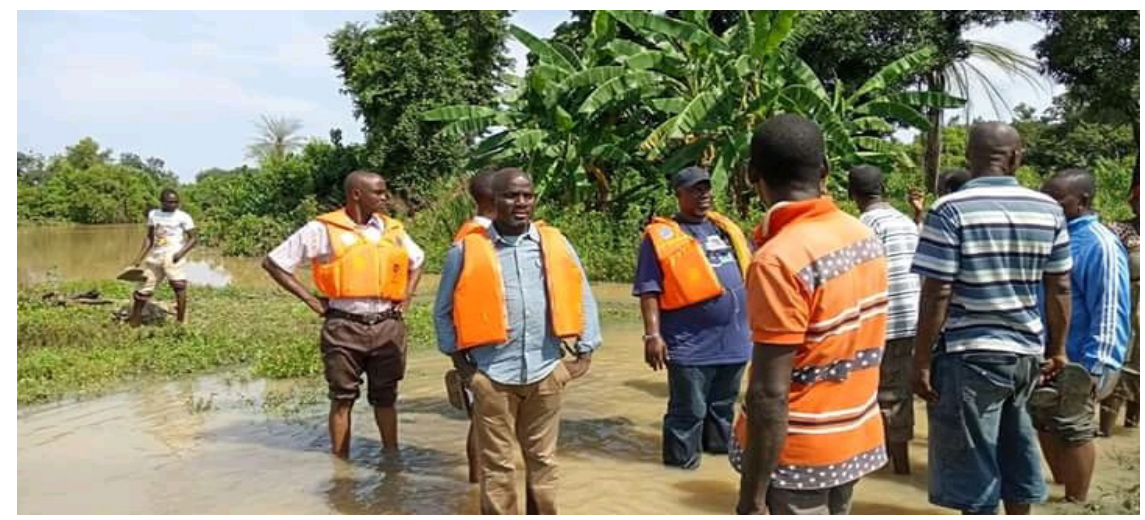

NEMA officials at Osomegbe

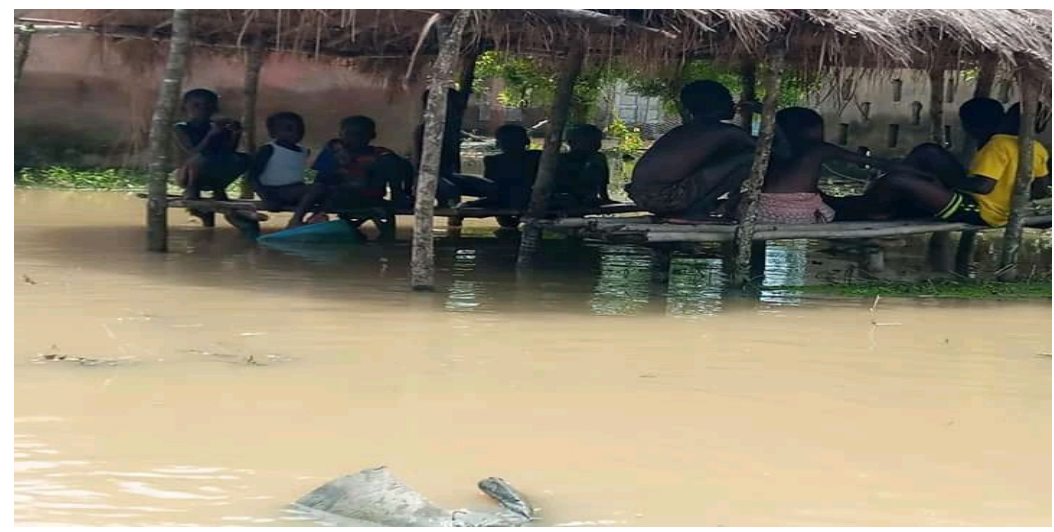

Submerged rest place at Agbabu-Ekperi 